\title{
Induction of Epithelial-mesenchymal Transition in MDCK II Cells
}

\author{
Agnieszka Pastuła* and Richard Lundmark
}

\begin{abstract}
Department of Integrative Medical Biology, Umeå University, Sweden
\end{abstract}
*For correspondence: agnieszka.pastula@umu.se

\begin{abstract}
[Abstract] Epithelial-mesenchymal transition (EMT) is a reversible process of epithelial cell transdifferentiation into a mesenchymal cell, that enables initiation of cell migration. EMT plays an important role in embryonic development, tissue repair and cancer metastasis. Better understanding of cellular and molecular events during EMT will not only provide novel insights on how mammalian organism develops and how epithelial tissues regenerate, but also can identify novel therapeutic targets for cancer therapy. Here we aim to provide a detailed protocol on how to induce EMT in Madin-Darby Canine Kidney (MDCK) II epithelial cell line and perform immunofluorescent staining on EMT-induced cells.
\end{abstract}

Keywords: Epithelial-mesenchymal transition, MDCK cells, Hepatocyte growth factor, Epithelial plasticity, EMT, Mesenchymal cell differentiation from epithelial cell

[Background] Epithelial cells are characterized by cell plasticity, that is the ability to adopt different cellular phenotypes (Carter et al., 2019; Yuan et al., 2019). Epithelial-mesenchymal transition (EMT) is a form of epithelial cell plasticity. During EMT epithelial cells disrupt cell-cell junctions, lose their polarity and change their shape from squamous, cuboidal, or columnar into spindle-like and become migratory, thus gaining the properties of mesenchymal cells (Kalluri and Weinberg, 2009). EMT can be evaluated by immunostainings and measurement of expression levels of markers such as E-cadherin, ZO-1, vimentin, fibronectin and $\mathrm{N}$-cadherin (Kalluri and Weinberg, 2009). The studies on EMT during the last decade centered mostly on the role of transcription factors e.g., Snail1/2, ZEB1/2, Twist and microRNAs (Gonzalez and Medici, 2014), cytokines like tumor necrosis factor-alpha (TNF- $\alpha$ ) and interleukin-6 (IL6) (Yadav et al., 2011; Li et al., 2012), and signaling mechanisms such as transforming growth factor beta (TGF- $\beta$ ) signaling and NF-KB signaling (Gonzalez and Medici, 2014; Song et al., 2014; Dongre and Weinberg, 2019). However, regulatory mechanisms of early stages EMT and the precise sequence of molecular events during EMT remain largely unknown.

Madin-Darby Canine Kidney (MDCK) epithelial cell line is a cellular model to study epithelial cell polarity and junctions (Dukes et al., 2011; Yonemura, 2014; Vidal-Quadras et al., 2017). MDCK II cell line is a strain, that originates from higher passage of parental MDCK cells (Dukes et al., 2011). MDCK II cells differ from parental MDCK cells in that MDCK II cells have leaky cell junctions. Importantly, MDCK cells can be cultured in a standard 2D cell culture system, as well as in a more physiologically relevant 3D cell culture system (Yonemura, 2014; Vidal-Quadras et al., 2017).

EMT can be easily stimulated in 2D cell cultures of MDCK II cells by treatment with hepatocyte growth 
factor (HGF), that decreases cell roundness, upregulates the expression of vimentin, and increases the cell distance to the first and the second neighbor cell (Farrell et al., 2014). Here we provide a detailed description of the procedure on how to stimulate EMT in 2D cell cultures of MDCK II cells. Additionally, we describe the procedure for immunostaining of EMT-induced cells for ZO-1, a tight junction protein, and vimentin, the classical EMT marker.

\section{Materials and Reagents}

1. Sterile Cell Culture Dish, $100 \times 20 \mathrm{~mm}$ (Sarstedt, catalog number: 83.3902 )

2. Serological pipettes: $5 \mathrm{ml}$ (Sarstedt, catalog number: 86.1253.001), $10 \mathrm{ml}$ (Sarstedt, catalog number: 86.1254.001), $50 \mathrm{ml}$ (Sarstedt, catalog number: 86.1256.001)

3. Tube $15 \mathrm{ml}$ (Sarstedt, catalog number: 62.554.502)

4. Tube $50 \mathrm{ml}$ (Sarstedt, catalog number: 62.547.254)

5. $1.5 \mathrm{ml}$ microtubes (Sarstedt, catalog number: 72.690.301)

6. Culture chambers: Lumox 8-well specimen slide detachable (Sarstedt, catalog number: 94.6150.801)

Note: The procedure also works with Falcon ${ }^{T M}$ Chambered Cell Culture Slides, 8 wells, (Corning, catalog number: 354118 ).

7. Laboratory bottle, borosilicate 3.3 glass, $50 \mathrm{ml}$ (VWR, catalog number: 215-3261)

8. Laboratory bottle, borosilicate 3.3 glass, $1,000 \mathrm{ml}$ (VWR, catalog number: 215-1595)

9. Aluminium foil

10. $\mathrm{ART}^{\mathrm{TM}}$ Barrier Specialty Pipette Tips: $10 \mu \mathrm{l}$ (Thermo Scientific, catalog number: 2140 ), $200 \mu \mathrm{l}$ (Thermo Scientific, catalog number: 2770), 1,000 $\mu \mathrm{l}$ (Thermo Scientific, catalog number: 2279)

11. Microscope slide holder

12. Cover slips Menzel Glaser $24 \times 60 \mathrm{~mm}$ (ThermoFisher Scientific, catalog number: E-4137)

13. Parafilm

14. MDCK II cell line (Merck/Sigma-Aldrich, catalog number: ECACC 00062107)

15. Eagle's Minimum Essential Medium (EMEM), $500 \mathrm{ml}$ (ATCC, catalog number: 30-2003)

16. Fetal bovine serum (FBS), $500 \mathrm{ml}$ (Gibco, catalog number: 10270-106) Note: FBS does not require heat inactivation.

17. Dulbecco's phosphate-buffered saline (DPBS) 1×, no calcium, no magnesium, $500 \mathrm{ml}$ (Gibco, catalog number: 14190-094)

18. Trypsin-EDTA (0.25\%), phenol red, $100 \mathrm{ml}$ (Gibco, catalog number: 25200056)

19. Recombinant Human HGF (HEK293 derived), 25 ug (Peprotech, catalog number: 100-39H)

20. Goat normal serum, $10 \mathrm{ml}$ (Agrisera, catalog number: AS10 1548)

21. Saponin, $10 \mathrm{~g}$ (Sigma-Aldrich, catalog number: S4521)

22. Paraformaldehyde (PFA), $1 \mathrm{~kg}$ (Sigma-Aldrich, catalog number: 16005)

23. Sodium chloride ( $\mathrm{NaCl}), 1 \mathrm{~kg}$ (VWR Chemicals, catalog number: 27810.295) 
24. Potassium chloride $(\mathrm{KCl})$, reagent grade, Reag. Ph Eur, $1 \mathrm{~kg}$ (Scharlau, catalog number: PO02001000)

25. di-Sodium hydrogen phosphate dihydrate $\left(\mathrm{Na}_{2} \mathrm{HPO}_{4} \cdot 2 \mathrm{H}_{2} \mathrm{O}\right), 1 \mathrm{~kg}$ (Scharlau, catalog number: SO03391000)

26. Potassium dihydrogen phosphate $\left(\mathrm{KH}_{2} \mathrm{PO}_{4}\right), 1 \mathrm{~kg}$ (Merck, catalog number: 1048731000$)$

27. VECTASHIELD ${ }^{\circledR}$ Antifade Mounting Medium with DAPI, $10 \mathrm{ml}$ (Vector Laboratories, catalog number: $\mathrm{H}-1200)$

28. Nail polish

29. Sodium hydroxide ( $\mathrm{NaOH}), 1 \mathrm{~kg}$ (Merck, catalog number: 1064691000)

30. Primary antibodies (Table 1)

Table 1. Primary antibodies

\begin{tabular}{lllll}
\hline & Antibody name & Host & Company & Catalog number \\
\hline 1 & Vimentin monoclonal antibody (V9) & Mouse & eBioscience & $14-9897-82$ \\
2 & ZO-1 polyconal antibody & Rabbit & Proteintech & 21773-1-AP \\
\hline
\end{tabular}

31. Secondary antibodies (Table 2)

Table 2. Secondary antibodies

\begin{tabular}{lllll}
\hline & Species reactivity & Fluorescent dye & Company & Catalog number \\
\hline 1 & Anti-mouse & Alexa Fluor $^{\circledR} 568$ & Life Technologies & A11031 \\
2 & Anti-rabbit & Alexa Fluor $^{\circledR} 488$ & Life Technologies & A11034 \\
\hline
\end{tabular}

32. Complete medium for MDCK II cells (see Recipes)

33. PBS $10 \times$ (see Recipes)

34. PBS $1 \times$ (see Recipes)

35. Blocking buffer (see Recipes)

36. Washing buffer (see Recipes)

37. $3 \%$ PFA (see Recipes)

38. $5 \%$ saponin (see Recipes)

\section{Equipment}

1. Counting chamber, type Burker (Hirschmann, catalog number: 8100201)

2. Fume hood

3. Eppendorf ${ }^{\circledR}$ Research $^{\circledR}$ plus pipette, 3-pack: 0.5-10 $\mu \mathrm{l}, 10-100 \mu \mathrm{l}, 100-1,000 \mu \mathrm{l}$ (Sigma-Aldrich, catalog number: Z683884)

4. Integra Pipetboy 2 (VWR, catalog number: 612-0927)

5. Heating and magnetic stirrer RH basic 2 (Dulova, catalog number: QSA337) 

6. Centrifuge VWR Compact Star CS4
7. $37^{\circ} \mathrm{C}, 5 \% \mathrm{CO}_{2}$ cell culture incubator
8. Standard phase contrast microscope
9. Confocal microscope Zeiss 710

\section{Software}

1. ImageJ (https://imagej.nih.gov/ij/download. html)

\section{Procedure}

A. Starting MDCK II cell culture

1. Prepare the complete medium for MDCK II cells (see Recipes).

2. Thaw a vial with frozen MDCK II cells.

3. Transfer the cells into a $15 \mathrm{ml}$ Falcon tube containing the complete medium.

4. Centrifuge the cells for $5 \mathrm{~min}$ at $1,500 \mathrm{rpm}(214 \times \mathrm{g})$.

5. Discard the supernatant.

6. Add $10 \mathrm{ml}$ of complete medium. Pipette up and down.

7. Transfer the cells into a cell culture dish.

8. Culture cells at $37^{\circ} \mathrm{C}, 5 \% \mathrm{CO}_{2}$ in cell culture incubator.

B. MDCK II cell passage

1. Pre-warm complete medium and trypsin.

2. Remove medium from the cells.

3. Wash with $10 \mathrm{ml}$ of DPBS.

4. Add $2 \mathrm{ml}$ of trypsin.

5. Incubate cells for $5 \mathrm{~min}$ at $37^{\circ} \mathrm{C}$.

6. Check under the microscope if cells are detached.

Note: If cells are not detached, continue incubation for $2-5 \mathrm{~min}$ at $37^{\circ} \mathrm{C}$.

7. Add $10 \mathrm{ml}$ of complete medium.

8. Pipette up and down.

9. Transfer the cell suspension into a $15 \mathrm{ml}$ tube.

10. Centrifuge the cells for $5 \mathrm{~min}$ at $1,500 \mathrm{rpm}(214 \times \mathrm{g})$.

11. Discard the supernatant.

12. Seed the cells in a new cell culture dish. Use split ratio of 1:5.

13. Culture cells at $37^{\circ} \mathrm{C}$.

C. Induction of EMT

Day 0 
1. Seed 16,000 cells/well in an 8 -well chamber slide.

Note: For the induction of EMT in MDCK II cells, the cells were passaged less than 10 times.

2. Incubate cells overnight.

\section{Day 1}

1. Prepare HGF stock $100 \mu \mathrm{g} / \mathrm{ml}$ and make aliquots:
a. Spin down the vial with lyophilized HGF.
b. Add $250 \mu \mathrm{l}$ of sterile BSA $1 \mathrm{mg} / \mathrm{ml}$ (in PBS) to the vial with HGF.
c. Mix by pipetting.
d. Spin down.
e. Make aliquots. Use sterile $1.5 \mathrm{ml}$ tubes.
f. Store the aliquots at $-80^{\circ} \mathrm{C}$.

2. Dilute the HGF stock with complete medium to final concentration $20 \mathrm{ng} / \mathrm{ml}$. Mix by vortexing.

3. Remove medium from the cells, that were seeded in the 8-well chamber slide.

4. Add $0.5 \mathrm{ml}$ of DPBS per well.

5. Remove DPBS.

6. Add complete medium containing HGF, use $0.5 \mathrm{ml}$ medium per well. Note: For the control, treat cells with complete medium without HGF.

7. Incubate the cells for $24 \mathrm{~h}$ at $37^{\circ} \mathrm{C}$.

D. Immunofluorescent staining and imaging

\section{Day 2}

1. Thaw:

3\% PFA (see Recipes)

Goat serum

$5 \%$ saponin (see Recipes)

2. Prepare:

Washing Buffer (see Recipes)

Blocking Buffer (see Recipes)

3. Remove culture medium.

4. Fix the cultures in 3\% PFA for $10-15 \mathrm{~min}$. Use $0.5 \mathrm{ml}$ of PFA/well.

Note: All immunostaining steps are performed at room temperature, except where otherwise provided.

5. Wash the cultures with PBS $1 \times$ (see Recipes). Use $0.5 \mathrm{ml}$ of PBS $1 \times /$ well.

6. Add $0.5 \mathrm{ml}$ of Blocking Buffer/well. Incubate for $1 \mathrm{~h}$ at room temperature.

7. Incubate the cultures with primary antibodies (Table 1), overnight, at $4{ }^{\circ} \mathrm{C}$. Cover the cultures with parafilm.

a. Dilute anti-ZO-1 antibody at a ratio 1:200.

b. Dilute anti-vimentin antibody at a ratio 1:500. 
c. Use Washing Buffer for dilution of antibodies.

d. Use minimum $200 \mu \mathrm{l}$ antibody solution/well.

Day 3

8. Remove antibody solution.

9. Wash with PBS 1×. Use $0.5 \mathrm{ml}$ of PBS $1 \times /$ well.

10. Incubate the cultures with fluorescent secondary antibodies (Table 2) for $1 \mathrm{~h}$.

a. Dilute secondary antibodies at a ratio 1:500.

b. Use Washing Buffer for dilution of antibodies.

c. Use minimum $200 \mu \mathrm{l}$ antibody solution/well.

d. Cover the cultures with aluminium foil to protect from the light.

11. Wash with PBS 1x. Use $0.5 \mathrm{ml}$ of PBS $1 \mathrm{x} /$ well.

12. Discard PBS $1 \times$.

13. Remove media chamber. Use removing device.

14. Mounting

a. Put few drops of mounting medium on a coverslip slide.

b. Put the coverslip slide on the top of the slide containing the cultures. Avoid bubbles.

15. Seal the mounted slide with nail polish.

16. Store the slides in a microscope slide folder at $4{ }^{\circ} \mathrm{C}$. Protect from light.

Day 4

Take images of the stained cells with a confocal microscope (Figure 1).

\section{Data analysis}

Confocal microscope images are analyzed with ImageJ software. In addition to phenotypical characterization by immunofluorescence, EMT-induced MDCK cells can be analyzed by western blotting, evaluation of cell roundness as well as measurement of the cell distance to the first and the second neighbor cell, as described by Farrell et al. (2014). 

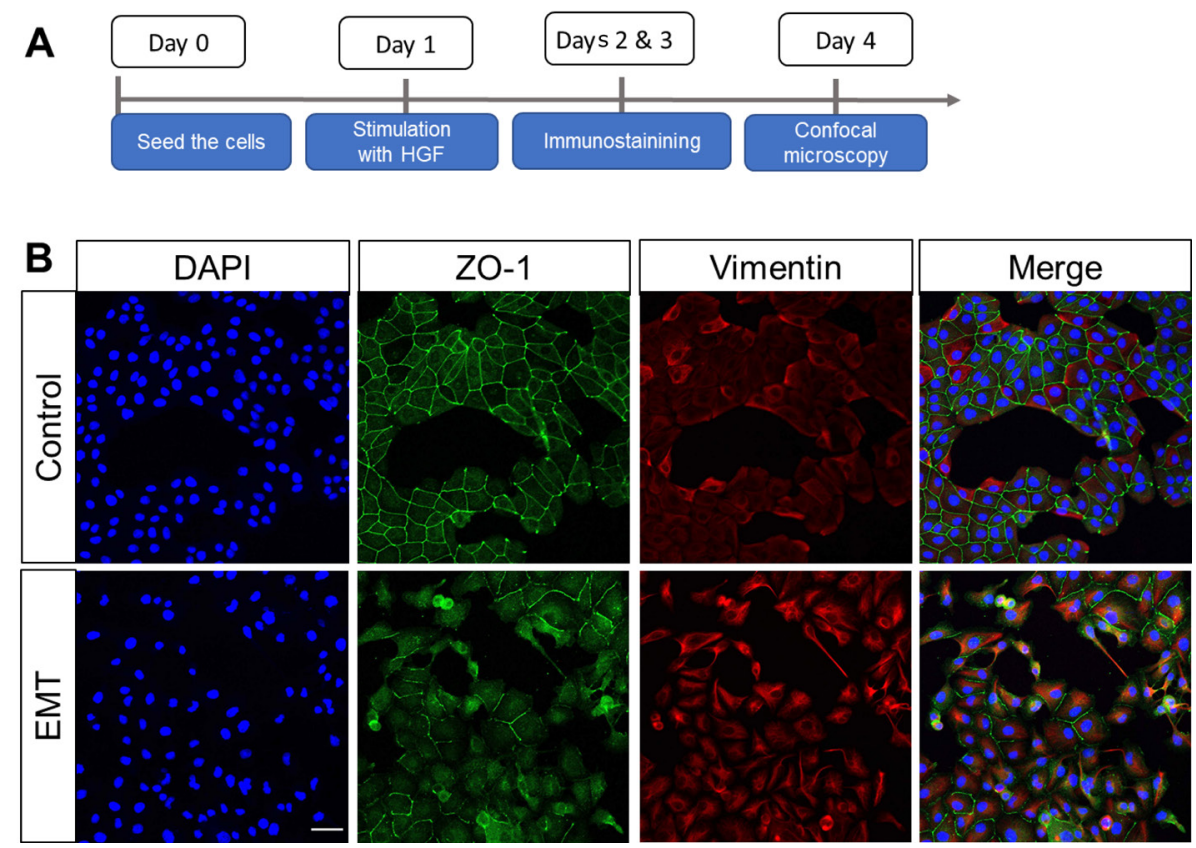

Figure 1. Phenotypical characterization of EMT in MDCK II cells. A. Experimental schedule: MDCK II cells were treated with hepatocyte growth factor (HGF) for $24 \mathrm{~h}$, fixed and then stained for EMT markers. B. Immunostaining for vimentin and tight junction protein-1 (zonula occludens1, ZO-1). DAPI was used for nuclear counterstaining. Objective 20x. Scale bar, $50 \mu \mathrm{m}$.

\section{Notes}

For successful and reproducible results, we recommend:

1. To strictly follow the manufacturer's guidelines on HGF storage and to avoid repeated HGF freeze-thaw cycles.

2. That MDCK II cells should be weekly observed under the microscope to monitor the stability of phenotype.

3. That MDCK II cultures should never be overgrown (avoid $>80 \%$ confluency).

4. That cell culture media should be exchanged regularly (avoid acidic medium, that can be identified by color change from pink into yellow, as it can induce EMT).

\section{$\underline{\text { Recipes }}$}

1. Complete medium for MDCK II cells

$450 \mathrm{ml}$ Eagle's Minimum Essential Medium (EMEM)

$50 \mathrm{ml}$ fetal bovine serum (FBS)

2. PBS $10 x$

$80 \mathrm{~g} \mathrm{NaCl}$

$2.2 \mathrm{~g} \mathrm{KCl}$

$14.2 \mathrm{~g} \mathrm{Na}_{2} \mathrm{HPO}_{4} \cdot 2 \mathrm{H}_{2} \mathrm{O}$ 
$2 \mathrm{~g} \mathrm{KH}_{2} \mathrm{PO}_{4}$

Adjust final volume to $1 \mathrm{~L}$ with distilled water

3. PBS $1 x$

$100 \mathrm{ml}$ PBS 10x

$900 \mathrm{ml}$ distilled water

4. Blocking buffer

$500 \mu$ goat serum

$100 \mu \mathrm{l} 5 \%$ saponin

Adjust final volume to $10 \mathrm{ml}$ with PBS $1 \times$

Store short-term at $4{ }^{\circ} \mathrm{C}$

5. Washing buffer

$500 \mu \mathrm{l}$ goat serum

$500 \mu \mathrm{l} 5 \%$ saponin

Adjust final volume to $50 \mathrm{ml}$ with PBS $1 \times$

Store short-term at $4{ }^{\circ} \mathrm{C}$

6. $3 \%$ PFA
$1.5 \mathrm{~g}$ PFA
$12.5 \mu \mathrm{IaOH} 6 \mathrm{M}$

Adjust final volume to $50 \mathrm{ml}$ with PBS $1 \times$

a. Combine all components in a glass bottle in a fume hood

b. Add magnetic stirring bar

c. Dissolve the PFA by stirring the solution on a magnetic stirrer at $56{ }^{\circ} \mathrm{C}$ in the fume hood

d. Store aliquots at $-20^{\circ} \mathrm{C}$

e. Avoid freeze-thaw cycles

7. $5 \%$ saponin

$2.5 \mathrm{~g}$ saponin

Adjust final volume to $50 \mathrm{ml}$ with distilled water

Make aliquots and store at $-20^{\circ} \mathrm{C}$

\section{Acknowledgments}

The protocol was adapted from Farrell et al. (2014). This work was supported by the Swedish Cancer Society (Cancerfonden, CAN2017/735). We acknowledge the Biochemical Imaging Center at Umeå University. We thank Wai-Lok Yau for critical reading of the manuscript.

\section{Competing interests}

The authors declare no conflicts of interest. 


\section{$\underline{\text { References }}$}

1. Carter, L. E., Cook, D. P. and Vanderhyden, B. C. (2019). Phenotypic plasticity and the origins and progression of ovarian cancer. In: The Ovary (Third Edition). Leung, P. C. K. and Adashi, E. Y. (Eds.). Academic Press: 529-545.

2. Dongre, A. and Weinberg, R. A. (2019). New insights into the mechanisms of epithelialmesenchymal transition and implications for cancer. Nat Rev Mol Cell Biol 20(2): 69-84.

3. Dukes, J. D., Whitley, P. and Chalmers, A. D. (2011). The MDCK variety pack: choosing the right strain. BMC Cell Biol 12(1): 43.

4. Farrell, J., Kelly, C., Rauch, J., Kida, K., Garcia-Munoz, A., Monsefi, N., Turriziani, B., Doherty, C., Mehta, J. P. and Matallanas, D. (2014). HGF induces epithelial-to-mesenchymal transition by modulating the mammalian hippo/MST2 and ISG15 pathways. J Proteome Res 13(6): 28742886.

5. Gonzalez, D. M. and Medici, D. (2014). Signaling mechanisms of the epithelial-mesenchymal transition. Sci Signal 7(344): re8-re8.

6. Kalluri, R. and Weinberg, R. A. (2009). The basics of epithelial-mesenchymal transition. The $J$ Clin Invest 119(6): 1420-1428.

7. Li, C. W., Xia, W., Huo, L., Lim, S. O., Wu, Y., Hsu, J. L., Chao, C. H., Yamaguchi, H., Yang, N. K. and Ding, Q. (2012). Epithelial-mesenchymal transition induced by TNF-a requires NF-KBmediated transcriptional upregulation of Twist1. Cancer Res 72(5): 1290-1300.

8. Song, F. N., Duan, M., Liu, L. Z., Wang, Z. C., Shi, J. Y., Yang, L. X., Zhou, J., Fan, J., Gao, Q. and Wang, X. Y. (2014). RANKL promotes migration and invasion of hepatocellular carcinoma cells via NF-kB-mediated epithelial-mesenchymal transition. PLoS One 9(9): e108507.

9. Vidal-Quadras, M., Holst, M. R., Francis, M. K., Larsson, E., Hachimi, M., Yau, W.-L., Peränen, J., Martín-Belmonte, F. and Lundmark, R. (2017). Endocytic turnover of Rab8 controls cell polarization. J Cell Sci 130(6): 1147-1157.

10. Yadav, A., Kumar, B., Datta, J., Teknos, T. N. and Kumar, P. (2011). IL-6 Promotes Head and Neck Tumor Metastasis by Inducing Epithelial-Mesenchymal Transition via the JAK-STAT3SNAIL Signaling Pathway. Mol Cancer Res 9(12): 1658-1667.

11. Yonemura, S. (2014). Differential sensitivity of epithelial cells to extracellular matrix in polarity establishment. PLOS One 9(11): e112922.

12. Yuan, S., Norgard, R. J. and Stanger, B. Z. (2019). Cellular plasticity in cancer. Cancer Discov. DOI: 10.1158/2159-8290.CD-19-0015. 